This PDF is a simplified version of the original article published in Internet Archaeology. Enlarged images and inline audio which support this publication can only be found in the original version online. All links also go to the online version.

Please cite this as: Graham, S, and Simons, J. 2021 Listening to Dura Europos: An Experiment in Archaeological Image Sonification, Internet Archaeology 56. https://doi.org/10.11141/ia.56.8

\title{
Listening to Dura Europos: An Experiment in Archaeological Image Sonification
}

\section{Shawn Graham and Jaime Simons}

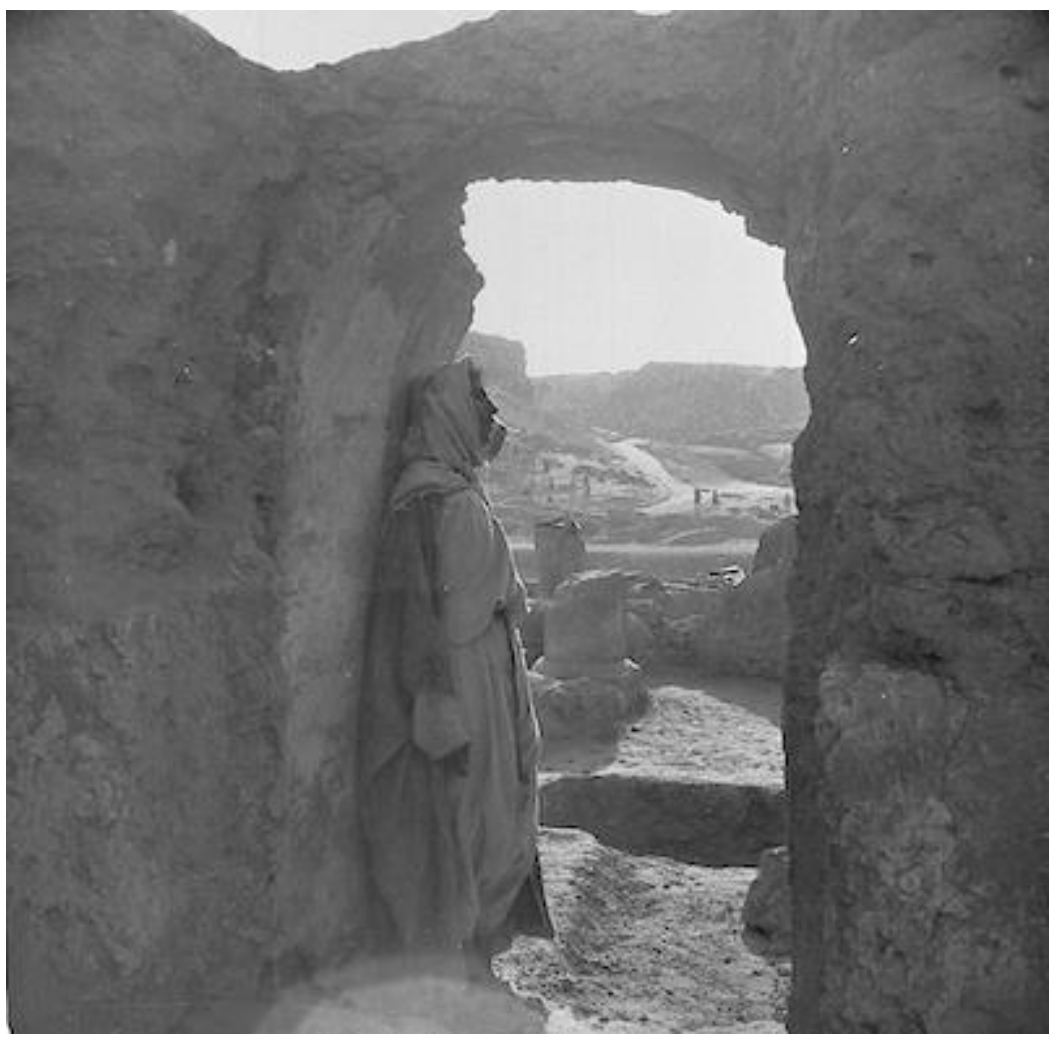

Man standing in doorway of block B2. Courtesy Yale University Art Gallery, DuraEuropos Collection, z-90; corresponds with Baird 2011, fig. 5

We present an experiment in sonifying archival archaeological imagery to make the act of looking at photography strange and weird. The sounds produced will then arrest us and slow us down, and make apparent to us the different ways that archaeological vision is constructed to particular effect/affect. It makes us alive to what is hidden or elided in the image itself; in slowing down, listening/looking/moving at one, we are moved towards enchantment, and engage in a kind of digital hermeneutics that reveals more than what the lens may have captured. 


\section{Introduction: The Sound of Archaeological Vision}

Jennifer Baird writes, of the Yale University-French Academy Expedition to Dura Europos in 1928-1937 and the way the expedition composed photographs for record keeping and publication, 'What might an archaeology of Dura have looked like if objects had been photographed as assemblages from single contexts rather than in typological or material-based groups?' (2011, 442).

We ask instead, what might the archaeology of Dura Europos sound like?

What can we hear, if we extend our senses through digital prostheses to extend our ability to sense the world? In this article we present an experiment in sonifying the archaeological imagery analysed by Baird (2011) as a way of enhancing our engagement with these archival photographs. By remediating digital copies of archival images through sound, sonification adds duration to them and, with duration, a linear kind of narrative structure emerges (on the potential of narrative emergence in digital media, see Copplestone and Dunne 2017). What is the story that these images sing? Tonal centres emerge, variations wind through and permeate the experience, and we react to this sound based on our own musical tastes, training, memories and emotions. Looking at the images while listening to them encourages a kind of synaesthetic reckoning where we unpack our own reactions. Ferraby, whose body of work includes the impressive Soundmarks project with Rob St John combining geophysical surveying and artistic reimagining of the data as both paintings and sound (Ferraby and St John 2020), calls this '.... poetry of algorithms designed to draw out past features of human life...' (Ferraby 2017, 2). Poetry, we might suggest, has always been about awakening an emotional, affective, response to see into the truer aspect of the thing.

Archaeological photography, as is well known, is not a straightforward process that creates an objective record of a site or an artefact. It is intensely creative and constitutive. For instance, both Baird and Morgan have both demonstrated how past moments in archaeological theory can be read from the composition of the photographs; Dan Hicks, in writing about the 'Brutish Museums' of British colonialism and the creation of ethnographic museums, describes the photographic record that underpins much of that archaeology as a record where the crime, the othering, and the control rendered by the photograph acts through a kind of weaponised duration $(\underline{2020}, 12-13)$. Edwards shows how the performativity of photography, its theatricality, can reveal the intentionality of the photographers beyond what they might have consciously intended (Edwards 2001). Riggs' survey of the history of archaeology shows clearly how intertwined the emergence and development of the discipline of archaeology is with the act of photography - to be an archaeologist was to also be a photographer (Riggs 2020). Clearly, there is much to read from archival archaeological photography beyond the 'mere' record of an excavation, an artefact. Shanks in 1997 encouraged archaeologists to move away from assuming photography simply records, towards creative interrogations of photography. To our knowledge, no one has sonified archaeological photographs. In this way, we set out to 'make trouble' in the way that McFadyen and 
Hicks argue, where photography is not about representation, but as transformation $(\underline{2020}, 6)$.

Sonifying photographs through their digital image data enhances what we might understand from these photographs, and pushes us to think differently about what else we might know from them; it is uncomfortable listening. Kramer and Noel (2020) remind us that this kind of remediation 'can illuminate new dimensions of digital archive through defamiliarization of visual representation and an expanded range of sensory comprehension'. In the digital humanities, this kind of action is known as 'deformance', a portmanteau of 'deform' and 'performance' (Samuels and McGann 1999). But aside from the new interpretative possibilities offered by image sonification, the act of translating archaeological information into sound opens up new ways to elicit what Sara Perry calls 'enchantment' (2019), a kind of engagement that aims to move us emotionally and push a fuller, richer engagement with the past. Nearly a century has elapsed since those excavations at Dura Europos; Baird's analysis shows clearly how the photography was used to 'other' the people for whom the site and its surroundings was their home. Sonifying, since sound and emotion seem to be so tightly bound, might be a way of engaging what Kisha Supernant et al. (2020) call a 'heart centred' archaeology, which aims to put archaeologists back into good relationship with the peoples from whom these data historically have been extracted. It is not for nothing that we say that we 'take' photographs.

Sonifying images is not done with the hope of pulling quantifiable data for understanding the past depicted in the image. It is for enchanting our engagement with our own archaeological practices in the era when the photos were taken, and this present moment when we re-engage. '...the use of digital sound design has made it possible to "amplify the meaning" of a historical event [‥] by inviting us "to hear an image while listening to its digitized data", [we establish] a new kind of historical hermeneutics of visual sources' (Kramer and Noël 2020).

While sound in the past is an active area of research, in terms of archaeoacoustics and soundscapes, the present experiment is to our knowledge the first to turn the techniques of sonification onto archival archaeological images (broadly similar work by Graham et al. 2020 sonifies artefact counts by geographic location to create a kind of sonic representation of space).

In principle, the process of sonification is straightforward. Just as the visual representation of data maps dimensions of the data to visual aesthetics - counts of artefacts along the $x$ axis of a grid, dates arrayed along the $y$ axis to indicate change over time - aesthetics of sound like duration, loudness, note, timbre, rhythms can be mapped to elements from the pixel data of the images (Graham 2016). There can be a great deal of artistry involved, as in the work by Graham et al. (2020) related to the sonification of artefact counts at Poggio Civitate. Sonification in general is a reproducible process though, where other researchers would hear the same results if they approached the same data with the same mappings. Sonification should also be 'intelligible', in that there is a systematic relationship between the elements that are sonified and the resulting sound (Hermann 2008). Last and Usyskin, in a series of experiments, found that time-series data could be made intelligible in sound even to listeners with no formal musical training; they could hear meaningful differences in the results that enabled the listeners to make informed deductions (Last and Usyskin $\underline{2015}$, 424). 
In this article, we propose a method of digital remediation of archaeological photographs, as an experiment to try to hear the different 'visions' of archaeology that are so encoded. This remediation confounds our normal sense expectations (Kramer 2018, 203). We systematically take image data and then procedurally map that data from digital copies of archaeological photographs into sound. We sonified the same images discussed by Baird 2011 in her article on photography at Dura Europos. We then listened to the pieces in the absence of the photos to record our thoughts and impressions; we listened to them again with the photos present and recorded what we saw/thought/heard. Kramer points out that listening to photographs is an exercise in a kind of synaesthesia, 'alienating' us and leaving us in an 'intermediary space between the visual and the aural - a fruitful perceptual interzone for consideration, interpretation, and intellectual discovery' $(\underline{2021}, 13)$.

\subsection{Digital remediation and sound}

Sonification is just one aspect of the broader field of sound studies. Sterne and Akiyama remind us how:

'[T]he relationship to sensation central to sonification ... is most distinctively characterized by the ability to transform data destined for one sense into data destined for another [...] this extreme plasticity lays bare the degree to which the senses themselves are articulated into different cultural, technological, and epistemic formations' Sterne and Akiyama 2012, 545.

The materials we study always have an impact on the kinds of history or archaeology that we can write; Kramer points to this plasticity as a way towards a 'digital hermeneutics' that revolves around the interplay of the sense of sight with the sense of sound (Kramer 2018, 196-7). In particular, Kramer (citing Walter Ong), points to the way sight makes us into external observers, while sound 'pours into' us. Kramer calls this a kind of digital synaesthesia that slows us down, an 'exploratory audio tactic' (Kramer 2021, 4).

\subsection{Listening is slow archaeology}

When one of us [SG] was a grad student, a new tool entered the archaeologist's toolkit the digital camera. That early model SG had access to could take 12 photographs before the memory was full and the battery was dead. The image quality was not particularly good; black and white cameras and film developed for print did not seem to be in any danger of disappearing. But of course, digital technology progresses rapidly, and we are at the point now where 'Slow Archaeology' proponents argue that the use of digital technologies in the field separate us (disenchant us?) from the work of knowing the field; they are instruments of an industrialisation of archaeological method that alienates us from the past (Caraher 2019; 2016).

The sonification of archaeological photographs therefore involves an element of slowing down, and of breaking the industrialisation (acceleration) of photography and archaeology. It takes time to create the sonification, and time to listen to it. It defamiliarises both the things in the images and, also, the images (digital files) themselves, giving us different avenues towards understanding. Kramer again: 
'By actively and critically playing with the representations produced as and through data, using computers to aid in the process of hearing images as well as viewing them, we can seek out fuller, richer interpretations of the materials we study. We can listen more deeply to what we are seeing' (Kramer 2021, 3).

This strikes us as similar to what Sara Perry has called for, a sense of critical enchantment (Perry 2019) and a way of engaging with archaeological materials that opens up new avenues for exploration and indeed wonder. The point of being alive to enchantment in archaeology is that (following Bennett 2001) it may move a person towards ethical action. We discuss archaeological labourers depicted in the Dura photographs below and how the sound of the photographs pushes us to hear their stories. It is worth pointing out that it is only comparatively recently that the people who know the archaeology best and from whose labour archaeological careers have been made have been seen to be skilled workers whose voices ought to be heard (see Mickel 2021; Perry 2018).

\subsection{What should we be listening for?}

Baird (2011) discusses photography as an act, as a practice, that interferes with time and constructs multiple times, including the moment the shutter clicked, the moment when the images would be looked at, and in the composition of the photograph itself, 'timeless' times that create an othering. The composition of the images create a 'particular past', but are themselves items with a history too. Her research on Dura Europos and the Yale-French expedition reminds us to consider that archaeological photography also means that we need to consider the act of photographing, what was included, what was excluded, perspectives, the framing of objects, and all the other apparatus of archaeological reconstruction - the act of photographing archaeological materials is also an act of trying to understand or write/create the archaeology. She draws our attention to the way time functions in these photographs, both:

'the practice of taking the photographs - the posing and framing - and the excavator's construction of a time in the image; thus, they reflect a temporal breach that constructed an East in which modern peoples are equated with ancient' (Baird 2011, 431).

Baird is able to discern multiple times in these photographs - a constructed 'timeless' past, a time of colonialism, the modern time when viewing the photographs, and the time into the future when they will be looked at again (see also Hicks 2020, 12-13, on how photographs of the destruction of Benin city become a weapon into the future for dispossessing and erasing African cultures).

Similarly, Morgan (2016) is able to witness in the archive of photographs from Çatalhöyük an evolution of archaeological thought. She carefully categorises the nature of each photograph, and, by mapping these counts over time, she is able, for instance, to see clear differences in shifts in social distance on site. The photos from the earliest period reduce the workers to part of the background (1960s); the materials from the early 2000 s have a viewpoint where the viewer is implicated in the scene, which Morgan interprets as reflective of a theoretical approach built around the multivocality of sources; the person taking the photo is not identified. The final time slice (the present) depicts many interpersonal relationships surrounding and permeating the archaeology. Given the growth of visual media over the last thirty years and the primacy of visual 
representation in our digital media information ecosystems, work such as Baird's and Morgan's is crucial for understanding not only how archaeologists construct the past, especially given the colonialism encoded in these photographs, but also for how various publics encounter and understand this past. Visual media are slippy; we need to introduce some grit, some pause for reflection. We do that by adding duration and time back into the act of viewing photographs. Baird writes,

'It is particularly ironic that one of the things missing from archaeological understandings of photography is essentially time (and time as more than a frozen moment of exposure), especially given the concern of archaeology with processes' (Baird 2011, 428).

Through sonification, we listen for, and over, time.

\subsection{Recovering time}

Photographs depict assemblages, 'agencements', objects not still but having come together or having been put together in deliberate, particular ways, and responding to each other or causing resonances in/for us (Hamilakis 2017, 175, invoking Deleuze and Guattari). Ruth Tringham and Annie Danis draw on the work of ethnographer Sarah Pink, who advocates for the use of digital remediations not to try to create an exact duplicate of some phenomenon (those assemblages), but rather to invite engagement that is embodied, to create connections and intimacies: the point is to evoke, not to represent. 'It is not enough to do sensory archaeologies, we must enact them (emphasis original; Tringham and Danis 2020, 54, citing Pink 2009, 143, 147). In earlier experiments mapping counts of archaeological materials and the coordinates of findspots from the site of Poggio Civitate (the data for which are housed in the open access repository Open Context) to note values, Graham et al. (2020) remixed the resulting 'chords' into an EDM-style (electronic dance music) track called 'Reflixivity'. The music has a powerful beat, and the note values create repeating musical figures that invite dancing. As a person dances and responds to the music, they quite literally embody the archaeological knowledge. They perform the knowing, and intimate embodied engagement.

'In dancing, we achieve a different kind of knowledge of the world that reconnects us with the physicality of the world (e.g. Block and Kissel 2001). The eruptions of deep time into the present (Fredengren 2016) - such as that encountered at an archaeological site - are weird and taxing and require a certain kind of trained imagination to engage with. But by turning the data into music, we let go of our authority over imagination, and let the dancers perform what they know.'

That experiment took the assemblages of archaeological materials, and added durational values; Hamilakis 2017 points to the multiplicity of times in an assemblage, and the ways that we might think about the 'agencement' of objects, coming together and articulating in certain ways over certain durations. In an archaeological photograph, these multiple paths and durations come together for that one instant the shutter clicks. Frieman and Gillings suggest that we need to think about how different sensory modalities blur together $(\underline{2007}, 8)$. Tringham and Danis say of photography that while images might be enhanced with sound, they remain still $(\underline{2020}, 64)$; if music derived from artefact counts can move the whole body, and an image contains within it evidence of the flows and agencement/assemblage of objects, then we might understand 
archaeological photography by remediating it into 'affairs of the whole body' (Frieman and Gillings 2007, 8, citing Geurts 2005, 169).

\subsection{The point}

To reiterate: The point of sonifying archival archaeological imagery is to make the act of looking at photography strange and weird. The sounds will then arrest us and slow us down, and make apparent to us the different ways that archaeological vision is constructed to particular effect/affect. It makes us alive to what is hidden or elided in the image itself; in slowing down, listening/looking/moving at one, the various times captured in the image are complicated and made to resonate with our own memories, archaeological training or experience. We are moved towards enchantment, and engage in a kind of digital hermeneutics that reveals more than what the lens may have captured. Moreover, we suggest that eventually we might find that archaeological photographs composed for particular motives might sound similar in ways that one could train the ear to detect, patterns that will in turn enable us to see/understand hidden similarities between photos of a particular era, or constructed towards a particular goal.

\section{Method for Image Sonification}

Scripts that we used for this experiment are available in a code repository.

Michael Kramer experimented with turning images into raw data formats, and then importing the data into the open source sound editing program Audacity. The resulting 'wall of sound' actively resisted useful engagement: it hurt too much to listen to. This prompted Kramer to think more carefully about the act of translation or transmediation from image into sound, which brought him to Michel Rouzic's Photosounder software. The way Kramer's source data, a photo of the Berkely folk festival (of Mance Lipscomb, born in 1895 and the son of former enslaved people) when sonified pointed to the absence or presence of the performer. This drew Kramer to ask penetrating questions of the era, and how these individuals were seen by their contemporaries - 'by turning this shadowy, silent photograph of Lipscomb [who is in shadow compared to the rest of the photo] making music at Berkeley in 1963 back into sound ... Photosounder helped me access a sharper, more accurate interpretive analysis of the historical moment' (Kramer 2018, 201). Indeed, the sonified image continued to point to the absence of the performer even more than the image itself suggested, and the role of Black Americans in the folk music scene in the 1960s.

In contrast to Kramer's careful study of a single image and its sound, we took inspiration from archaeological field survey in that we wanted to create a standardised approach to different images to enable comparative results. In our case, we considered each 'image' to be a field that we would 'fieldwalk' sonically, retrieving image data from the same relative location in each field. We wanted to deploy a method that could be replicated, and did not use proprietary software with a graphical interface. After exploration and much experimentation, we settled on a version of the Python programming language adapted explicitly for music, Jythonmusic, (Manaris and Brown 2016).

We modified a script that comes bundled with the environment for image sonification (https://jythonmusic.me/, ch. 7 'Sonification and Big Data', image sonification, Manaris and Brown 2016) so that it would sonify the same relative pixel positions for each image, 
and map the resulting notes to a major scale. Every input image was rescaled to 400 pixels wide, with each beat in the music representing one column of data from the image. With four beats to the bar, there were 100 bars, so every image ends up having the same duration. The process captures transects of the pixel data across the image at a quarter of the image's height, at a half, and at three-quarters. Notes are created for each pixel by mapping its RGB value $0-255$ to pitch, duration, and dynamic. Even though these are black and white images, each pixel has three values. The luminosity of a pixel is mapped to the pitch (the brighter, the higher the note). Duration of a note is derived from the red value of the rgb colour value; intensity is derived from the blue value.

In Baird's original discussion of the photography of Dura Europos and the Yale-French Academy Expedition, she drew attention to the ways certain photographs could be read along colonialist dimensions, or how workmen become objectified in the photos while members of the Expedition literally stand out in the photos, creating a fantasy of the East for consumption by both archaeologists and the public 'back home'. We first listened to these sonified images in the absence of the photographs and attempted to categorise what we were hearing along two axes, the first being the intensity and energy of the piece, the second being the emotional content of what we were hearing. We also made notes about any associations or memories or other articulations of thought prompted by the music. We then listened again but with the photographs displayed in front of us.

Work in the Digital Humanities likes to speak of 'distant reading' or 'distant viewing', corpus-level analytical approaches that try to use computational approaches to see aggregate patterns. Here, we're invoking another one of the 'moves' of DH (see Liu 2020) by deforming our engagement with archaeological photography, remediating it (Manovich 2001) into a new sensory regime to remake our understanding of what archaeological photography does (see Gibbs and Owens 2013).

\section{Results}

The piece numbers correspond with the original figure numbers in Baird 2011, thus our Dura-Song- 1 is a sonification of Baird's figure 1; we encourage the reader to listen first, then look at the image and re-listen. The images that we discuss in depth below are reproduced in that section. We will refer to images in the discussion by reference to their original figure numbers in Baird 2011, hence 'B-fig. 1'.

SG created the sonifications en masse by having the script run on each image in a folder in turn. Then, JS listened to them without looking at the images or having seen them before; for each image they gave an impressionistic score for its intensity. For each image in turn, they made free notes on the emotional characteristic of the images.

But how to communicate sound in print about images? To complete the circle, we can render our results back into a single visual by scoring our reflection in terms of a sentiment analysis (Table 1). Each word of our impressions per image is compared against the AFINN lexicon of words (available through the tidytext package for the $R$ programming language) coded as having positive or negative connotations, ranging from +5 (very positive) to -5 (very negative). This is an unsophisticated form of text analysis, working at the level of unigrams (single words) only, but since our notes are not long passages of text but rather descriptive words that struck us as we listened, it is a 'good enough' data move. Thus, each image can be graphed along these two axes. 
Table 1: Original emotional responses and impressions of the intensity of the resulting image sonifications prior to looking at the images

This tables contains sound files, only playable online

https://intarch.ac.uk/journal/issue56/8/full-text.html\#table1

\begin{tabular}{|c|c|c|c|}
\hline $\begin{array}{l}\text { Baird } \\
\text { Figure }\end{array}$ & Original Emotional Response & $\begin{array}{c}\text { Intensity } \\
\text { (impression) }\end{array}$ & $\begin{array}{c}\text { Emotional } \\
\text { Score } \\
\text { (AFINN) }\end{array}$ \\
\hline
\end{tabular}

Sad but sweet. Nostalgia - longing.

$1 \quad$ Started pleasant, abrupt end. Feels like a song about separation and

52

Song 1

the journey to find something

$2 \quad \begin{aligned} & \text { Intense, insistent. Hopeful } \\ & \text { nostalgia remembering }\end{aligned}$

62

Song 2

Muted joy. At beginning, more

3 melancholic as it goes along.

Sounds like it's looking for

3.5

3

Song 3

something. Esp. with the sonar

$4 \quad$ Grief, sadness

7.5

$-2$

Song 4

$\underline{5}$

Nostalgic but also hopeful near

midpoint

5.5

2

Song 5

6

Alert but nostalgic storytime feel 9

$-1$

Song 6

Bit more sad at parts than the others, more melancholic and

7 depressed. Slower melody. Tragic. 6

Faster bits are intense and alert but not joyous

8

Adventurous. Happier than previous

6.5

2

Song 8

$\underline{9}$

Intense, stressed. Melancholic at parts

8

$-1$

Song 9

10 Determined. Closer to happy but still a bit short. Striking

7.5

5

Song 10

11 Joyful and nostalgic

7.5

3

Song 11

Nostalgic but hopeful then more

12 melancholic then almost hopeless. 8

Fragile hope at end

Song 12 


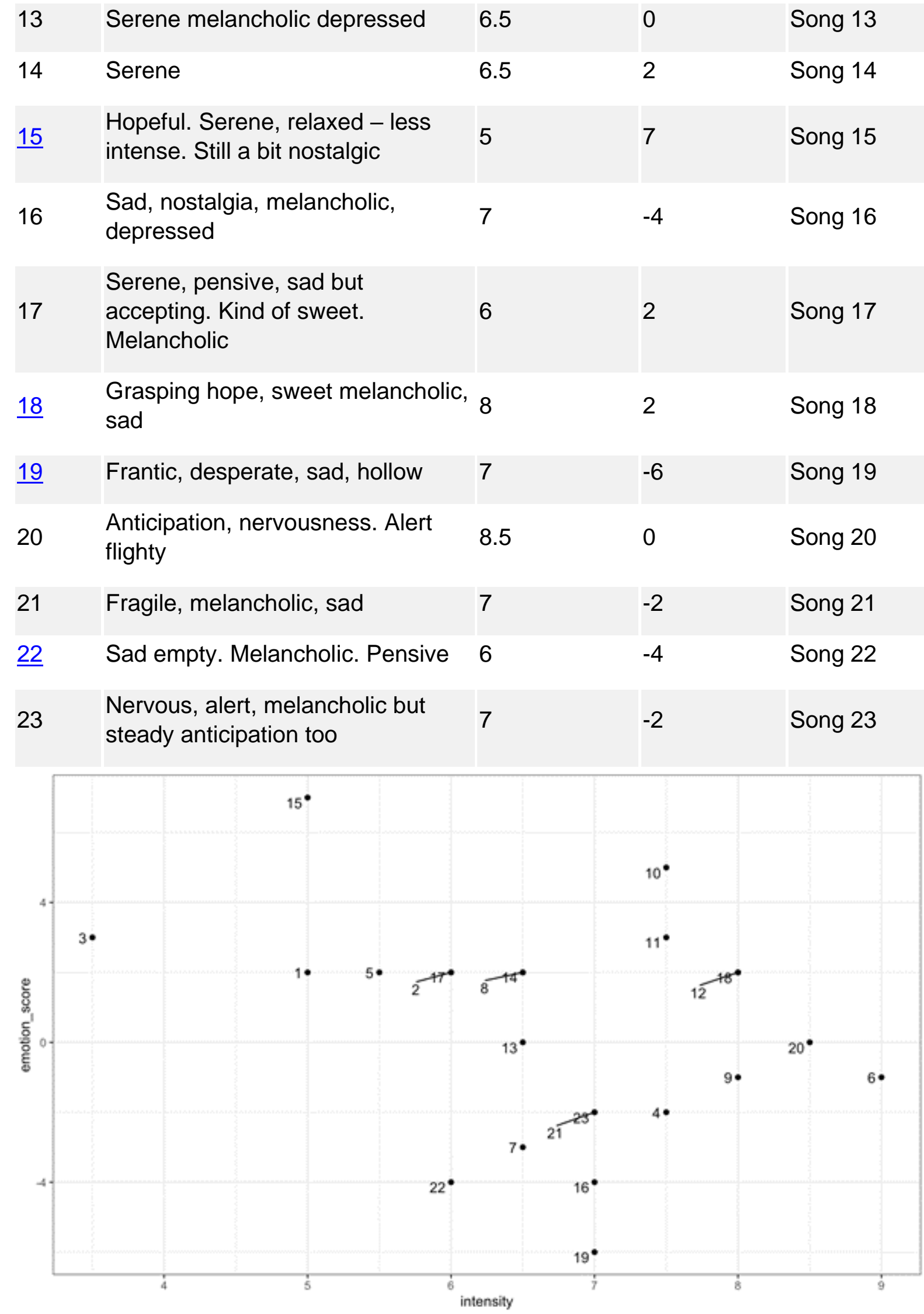

Figure 1: A visualisation of our impression of the intensity of the music on a scale of 110 versus our description of the emotions in each piece as scored using the AFINN lexicon for sentiment analysis 
Figure 1 does not represent the 'truth' of the matter, but just a truth; it is a visualisation (ironically) of our overall impressionistic listening to the 23 sonifications created for the purposes of communicating in print, at a glance, what it is like to listen to all of these pieces.

What is interesting here is that the clustering we can observe on this graph when we look at the relevant images seems to imply that the similarities emerge from broad patterns of light and dark, blocks of action and focus versus gaps. As an experiment, we colourised the photographs using a neural network. That algorithm extrapolates from the pixel colour values in the black-and-white photos to map the subtle shades of grey to colour values in its model (which it learned from training photographs; thus, as Drimmer 2021 notes, the resulting colours are what colour photographs were capable of rendering in the past, not the actual colours). The resulting music/sonification to our ears did not make any meaningful differences from the same photograph as originally sonified (in any event, the ethics of colourising photographs is a debate beyond the present contribution, but one we intend to address in a future work).

Because notes have duration, and thus what we hear emerges as a function of which notes and for how long they overlap (forming harmonies, or chords, or other musical figures), it's entirely possible that subtle differences might emerge, that could affect our emotional engagement with the piece. However, we do not feel that the overall structure of the resulting piece is all that different - that the black-and-white images contain within themselves enough relative difference in their colour values (remembering that the subtle shades of grey are nevertheless formed by rgb values) and that the sonification picks that up.

Once all sonifications were created, and the initial responses to them were made in the absence of the photographs, we then re-looked at the images through the lens of Baird's analysis, re-listening and re-considering our initial notes; we would write longer responses at this point. The duration of the sound acts as a focus for attention as we look.

\section{Discussion}

In her article, Baird begins by exploring how time is constructed in the Dura photographs. Since the remains exposed by the team were not conserved or protected, the first task of the images is to arrest time decay, to create a carefully staged, timeless archaeological moment.

'The times in these photographs can thus be conceived of as ancient, colonial, present, or even future: ancient, as a record of a construction of a perceived past; colonial, as a record of the uncovering and possession of that past by the Yale-French Academy excavation that took the photographs; present, as a record of the act of taking and then viewing the photographs; and future, as a record that could then, once catalogued and archived, be available implicitly for a future viewer' (2011, 429).

Baird discusses the image of the 'House of Lysias in block D1' (Fig. 2; Baird's fig. 1) as demonstrating the stoppage of time to create an archaeological moment. The 
overburden is removed, everything is cleaned down to the floors and mudbrick walls. There are no people populating the image. It is a mosaic of light and dark with a central room in brilliant sunshine, surrounded by shadows. As we listen to Figure 2 (Baird's fig. 1), we hear something that sounds like 'a song about separation and the journey to find something'. The interplay of notes creates harmonies that give a sense of sad nostalgia and longing. Contrary to the intent of the excavators, the image-as-song doesn't create a sense of timelessness or arrested decay, but rather, one of loss, archaeology as a brief flicker in the biography of the city, a final moment in the light. We are reminded forcefully of the destruction of archaeology, of the erasure it perpetuates onto the people of the past, and of the emptiness that is often left behind once the artefacts are removed.

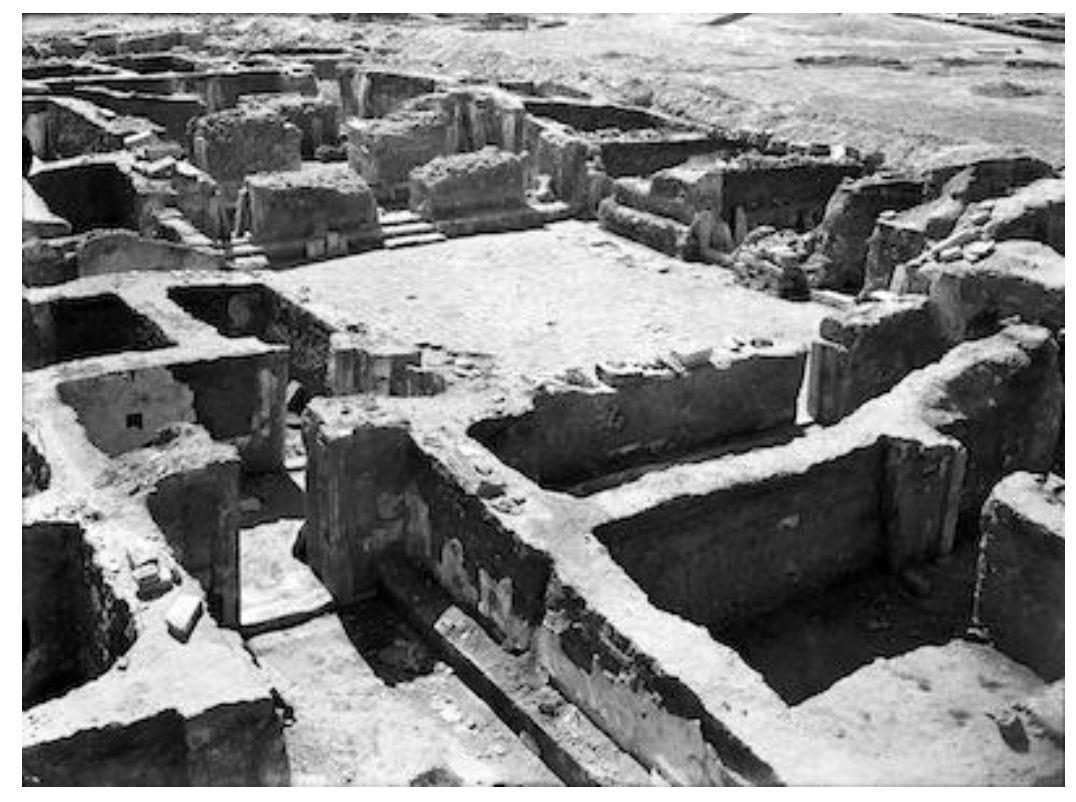

Figure 2: House of Lysias, Block D1. Courtesy Yale University Art Gallery, Dura-Europos Collection, k-327; corresponds with Baird 2011, fig. 1.

But what of other images of architecture? Figure 3, Figure 4 and Figure 5 (Baird's figs 2, 3 and 5) depict architecture with Syrian workmen in the background, used for scale. The composition of these photos uses people as living scale bars, as props for the archaeological research. In each of these, there is a high pitched 'pinging' that insists on your attention, a kind of telegraph staccato that both grabs our attention and fosters a sense of dread, but also puts us in mind of the transformation of knowledge and information into small packages - bits, if you will - that can be transmitted through sound. 


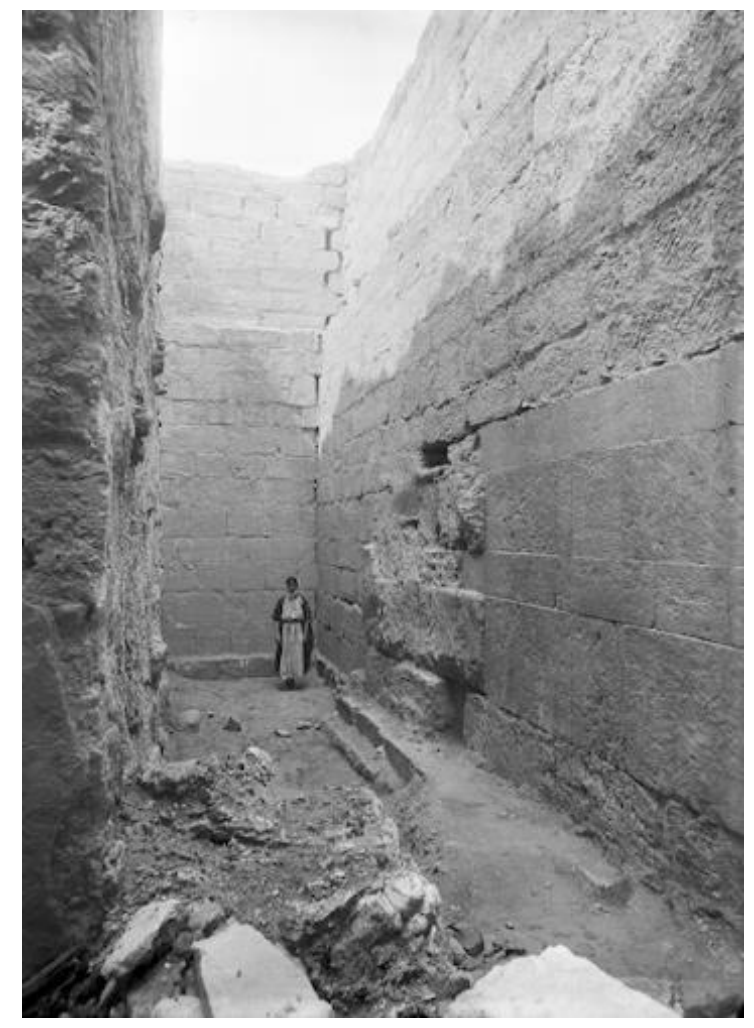

Figure 3: Man standing inside Tower 1, ancient fortifications. Courtesy Yale University Art Gallery, Dura-Europos Collection, c-172; corresponds with Baird 2011, fig. 2.

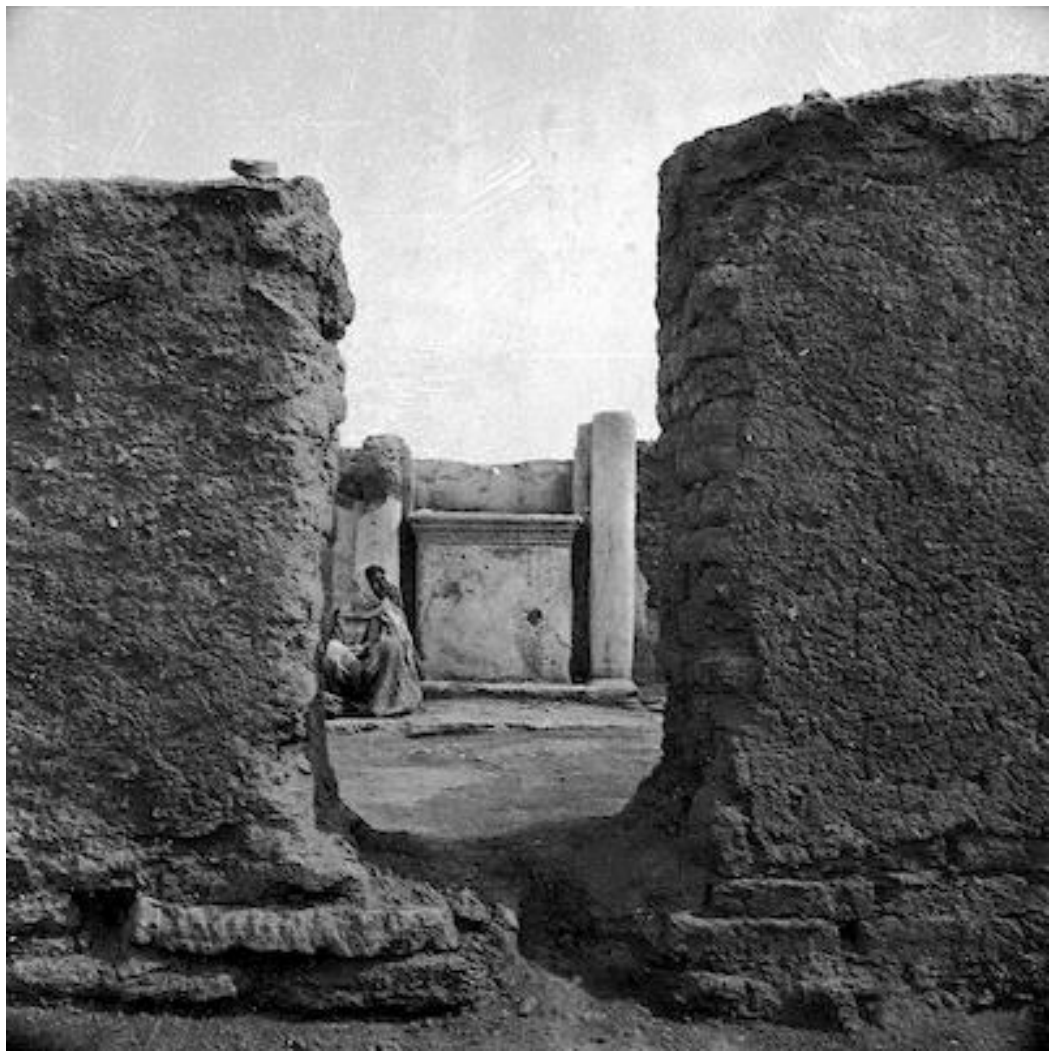

Figure 4: Worker inside the Temple of Azzanathkona. Courtesy Yale University Art Gallery, Dura-Europos Collection, Fx-8; corresponds with Baird 2011, fig. 3. 


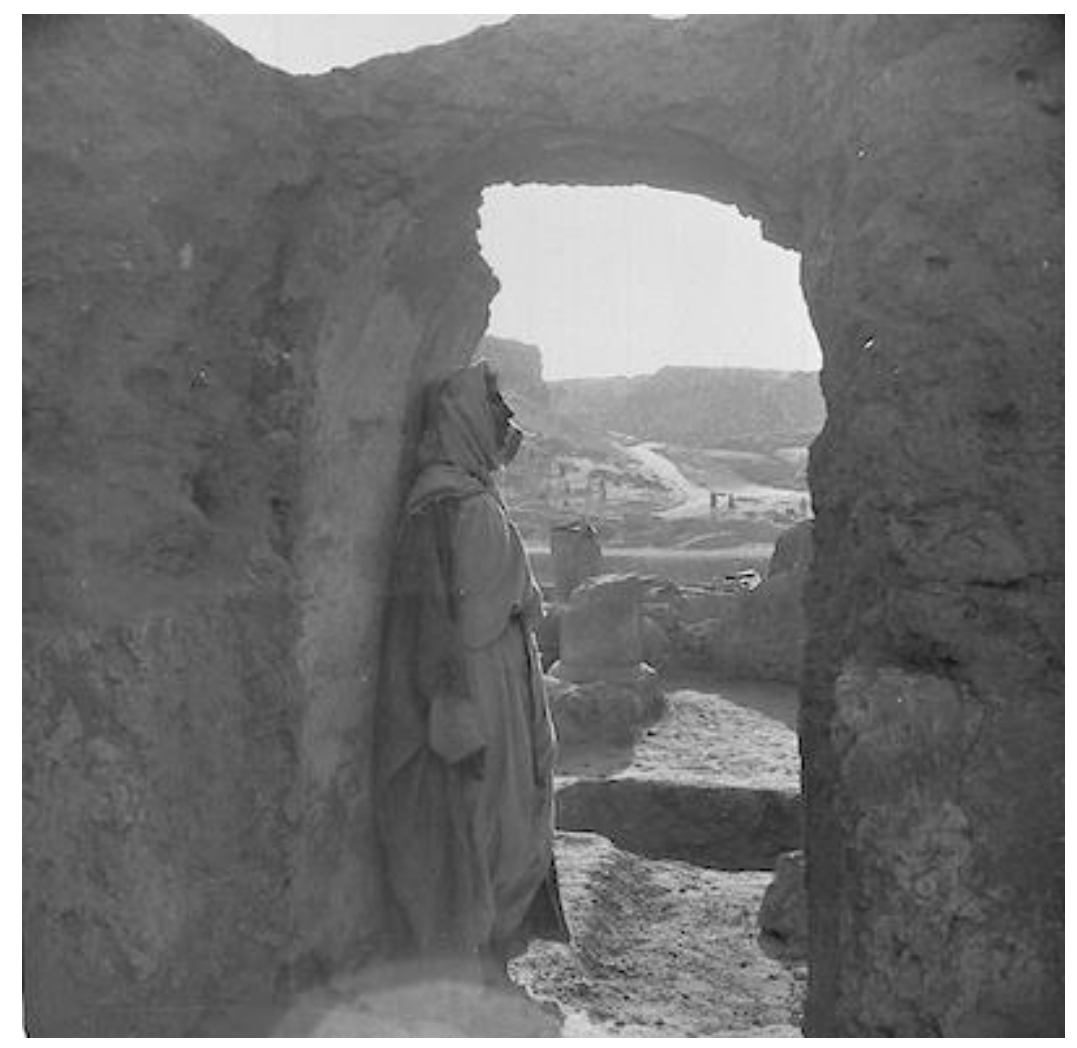

Figure 5: Man standing in doorway of block B2. Courtesy Yale University Art Gallery, Dura-Europos Collection, z-90; corresponds with Baird 2011, fig. 5.

Alternatively, we can hear in this a reflection of a submarine's sonar ping or anti-aircraft radar; militaristic modes of searching that push us to reflect on field archaeology's early connection with military men and military organisation. Sonar and radar reflecting off the large ruins, the architectural elements that survive; presaging modern archaeology's remote sensing abilities that pick up the finest details. Like the photomosaic from georadar, the immense labour it takes to create the work is hidden entirely, pushed to the background, forgotten. 


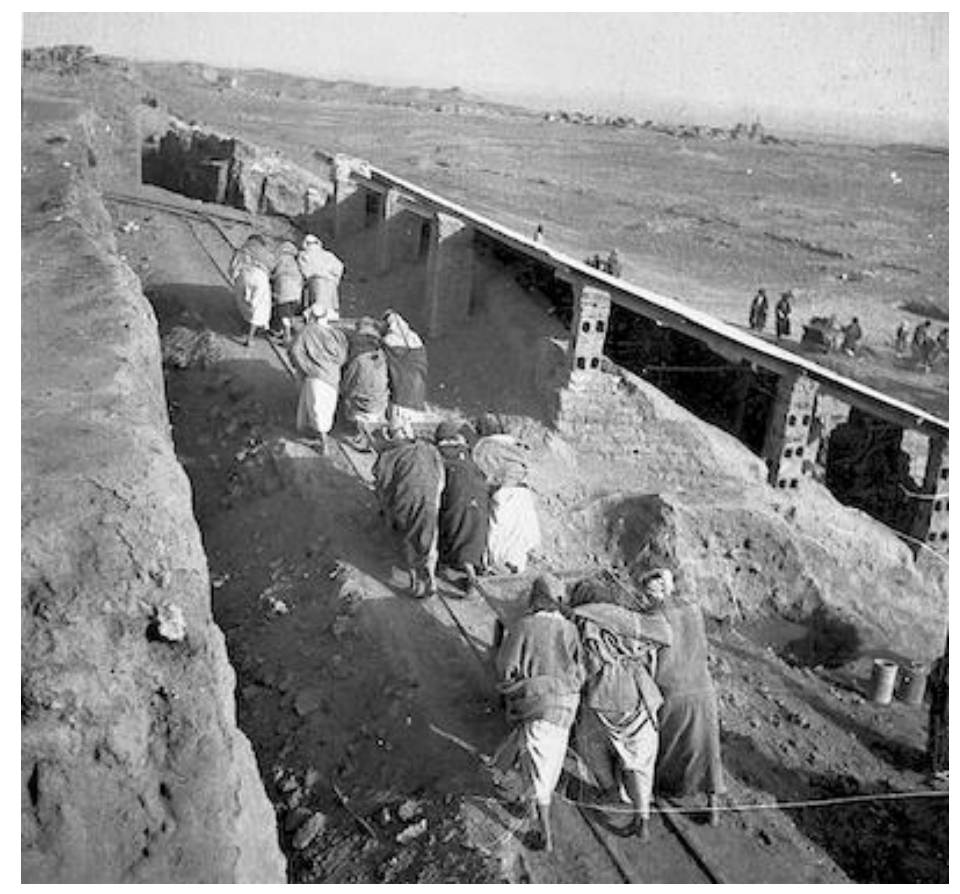

Figure 6: Workers pushing removed dirt in rail carts. Courtesy Yale University Art Gallery, Dura-Europos Collection, z-92. Corresponds with Baird 2011, fig. 15.

Figure 6 (Baird's fig. 15), which depicts teams of workmen toiling to push minecarts filled with rubble out of the site, struck us, when sonified, as serene, hopeful and relaxed: the very antithesis to what is depicted. And yet, while we cannot see the photographer, presumably a member of the Yale team, we know that it isn't him who is toiling to shift the rubble. While the piece is fairly active in its opening moments, it settles down into an almost trudging, repetitive pace, perhaps reflecting the composition of the photo into groups of workers, matching their no doubt slow labour to push the carts along the track. The interplay between the image and the sound drives home the long-standing archaeological habit to erase the labour of precariously employed, racialised individuals from the narrative told.

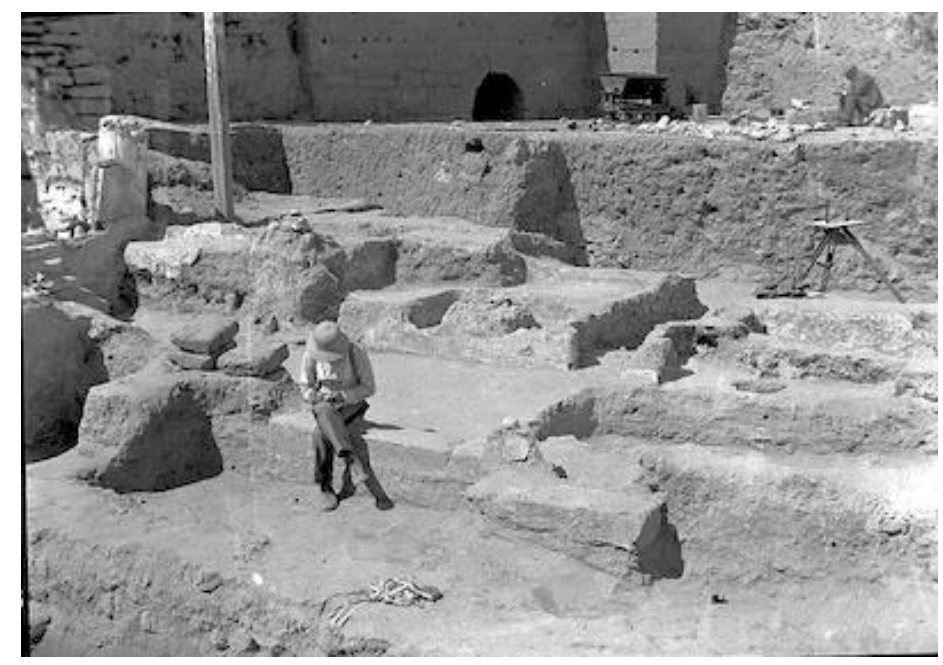

Figure 7: Yale expedition members taking notes on excavated area of the Mithraeum. Courtesy Yale University Art Gallery, Dura-Europos Collection, g974b. Corresponds with Baird 2011, fig. 9. 


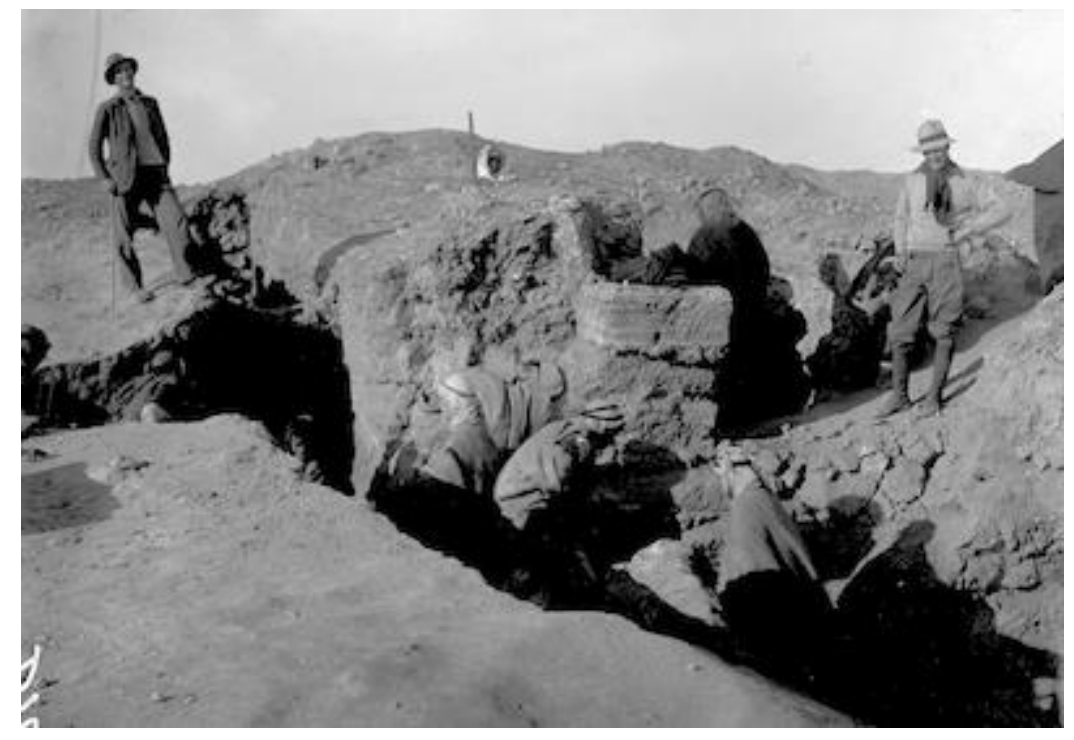

Figure 8: Yale-French Academy team members above trench on main street. Courtesy Yale University Art Gallery, Dura-Europos Collection, d108. Corresponds with Baird 2011, fig. 10.

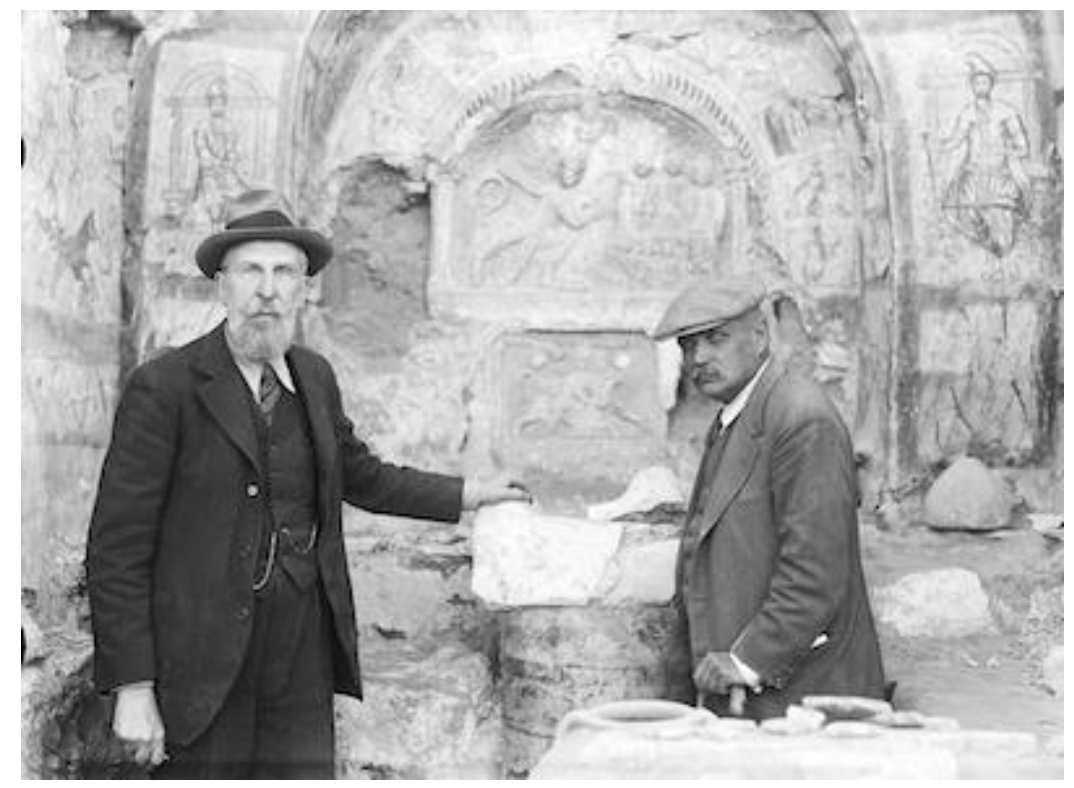

Figure 9: Cumont and Rostovtzeff in the Mithraeum. Courtesy Yale University Art Gallery, Dura-Europos Collection g852a. Corresponds with Baird 2011, fig. 11.

Photos that actually depict members of the Yale team, Figure 7, Figure 8 and Figure 9 (Baird's figs 9-11) are framed so that these individuals dominate the composition. We hear in Figure 7 (Baird's fig. 9), which depicts Yale members taking notes in the Mithraeum, a kind of stressed, unpleasant melancholy, with discordant notes midway; in Figure 8 (Baird's fig. 10), Yale members pose at the top of the trench, facing the camera while workers toil away below with their backs turned. The sound for this piece gives a sense of determination, with individual notes rather than chords and dissonance. Figure 9 (Baird's fig. 11) sounds joyful and nostalgic, with slower mournful sections bracketed by higher, more playful notes. In Figure 7 (Baird's fig. 9), the Yale member is some distance away from the camera, head down, looking at their notebook; in Figure 8 (Baird's fig. 10), the members are in the midground but at either side of the photo, while 
in Figure 9 (Baird's fig. 11) Cumont and Rostovtzeff, the directors of the expedition, are in the foreground looking directly at the camera, on either side of an architectural fragment. We can think of these images as a sequence zooming in towards the leadership of the Yale team; as we zoom in, and as the faces and poses grow clearer and more central, the sound changes from discord to joyful; dare we say, triumphal?

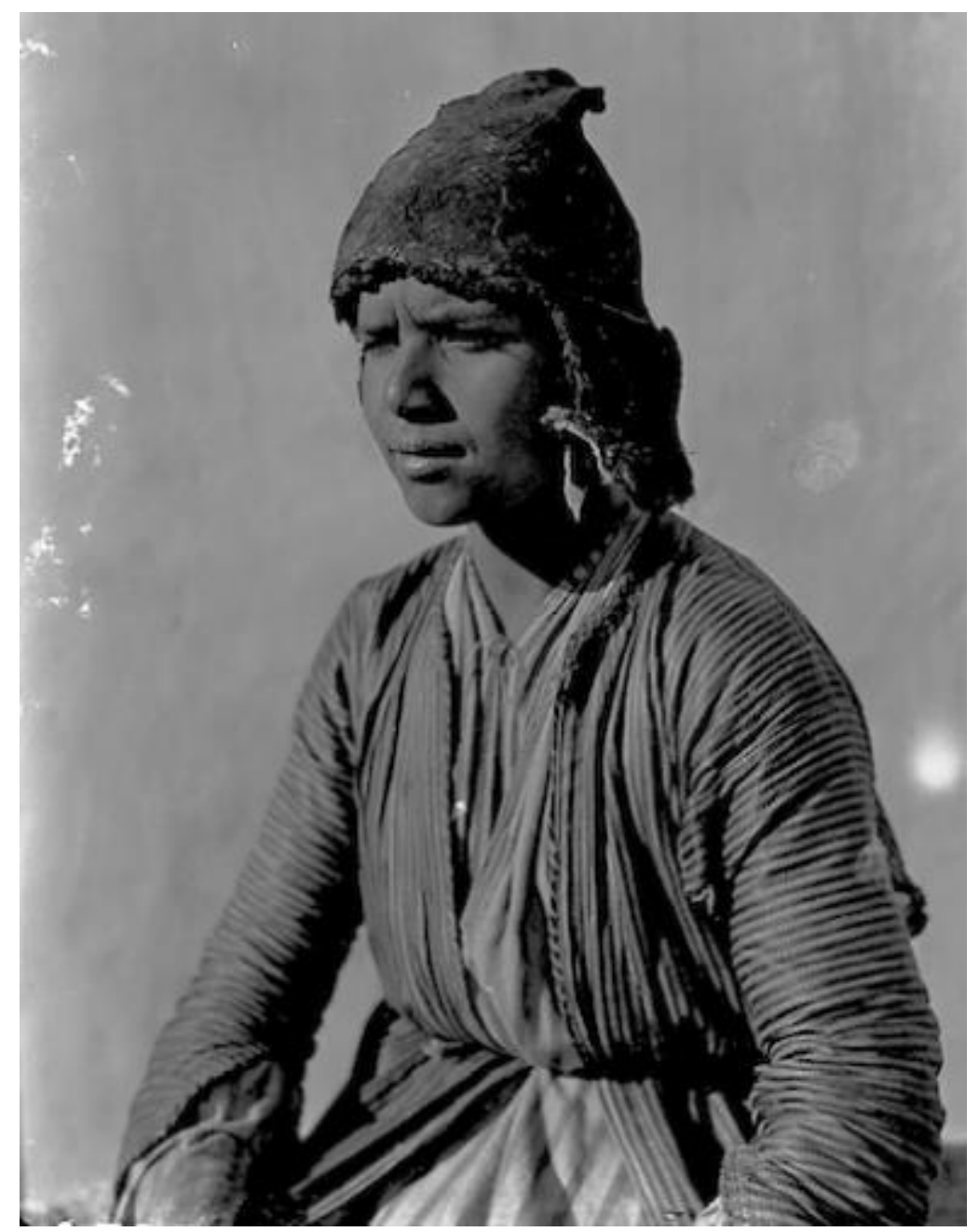

Figure 10: Young man wearing an ancient textile cap. Courtesy Yale University Art Gallery, Dura-Europos Collection g-785. Corresponds with Baird 2011, fig. 4.

The interplay of individuals and their composition in the frame seems to have a meaningful difference on the emotive quality of the music. Figure 10 (Baird's fig. 4) is meant to show off textiles recovered from the site; a young man is made to wear the woven cap. He sits, slightly turned to the left. We can see his full face, and the details of his clothing. We might expect that the music here would be similar to that in Figure 9 (Baird's fig. 11), where the two men are front and centre. And yet, the music carries overtones of grief, a pensive sadness; there are long moments of near silence, but towards the end, an upwelling of sound that is mindful of hope. When we look at the image and listen at the same time, the sense of grief deepens. It makes us wonder what the boy was thinking about. He could just be squinting into the sun, but he also looks sad. When the notes drop out and become almost entirely inaudible, it made us think about his life as well as his death. What did he think about excavating his heritage? What did he think, or what would he think, about where it ended up? Or, who he was working under? Did he speak the language of the Yale Expedition team? Did he feel the 
grief that we hear in the sonification? Looking at the image for such a prolonged time in addition to hearing the image gives us time for contemplation and drives home how much about this excavation was not captured by its excavators.

Baird points to the way archaeological labour and photography was gendered at Dura and at the contemporary excavation of Verulamium led by Mortimer Wheeler, juxtaposing two photographs showing women archaeologists. In both, the women are cleaning mosaic floors with brushes. As we listen to both these pictures we hear a kind of sad nostalgia, a serene, sweet and pensive melancholy. When we look at the images while listening, the highs and lows of this piece made us think of the action captured the sweeping back and forth of the person's cloth as they clean the mosaic. The imageas-sound is very contemplative, and easy to imagine the person sweeping to the tempo in a way that re-establishes action and movement in an otherwise static image. Listening to Baird's figure 17 of Verulamium, we wonder if and how the difference in colour of the clothing between these women and the darker robes or attire of the men (workers and archaeologists) may change the song. The song draws our attention away from the mosaic on display and makes us wonder about how the women experienced the excavation. It ends very abruptly - the abruptness, the violence of the ending... Did they experience gendered violence? What was their relationship to the men on site like?

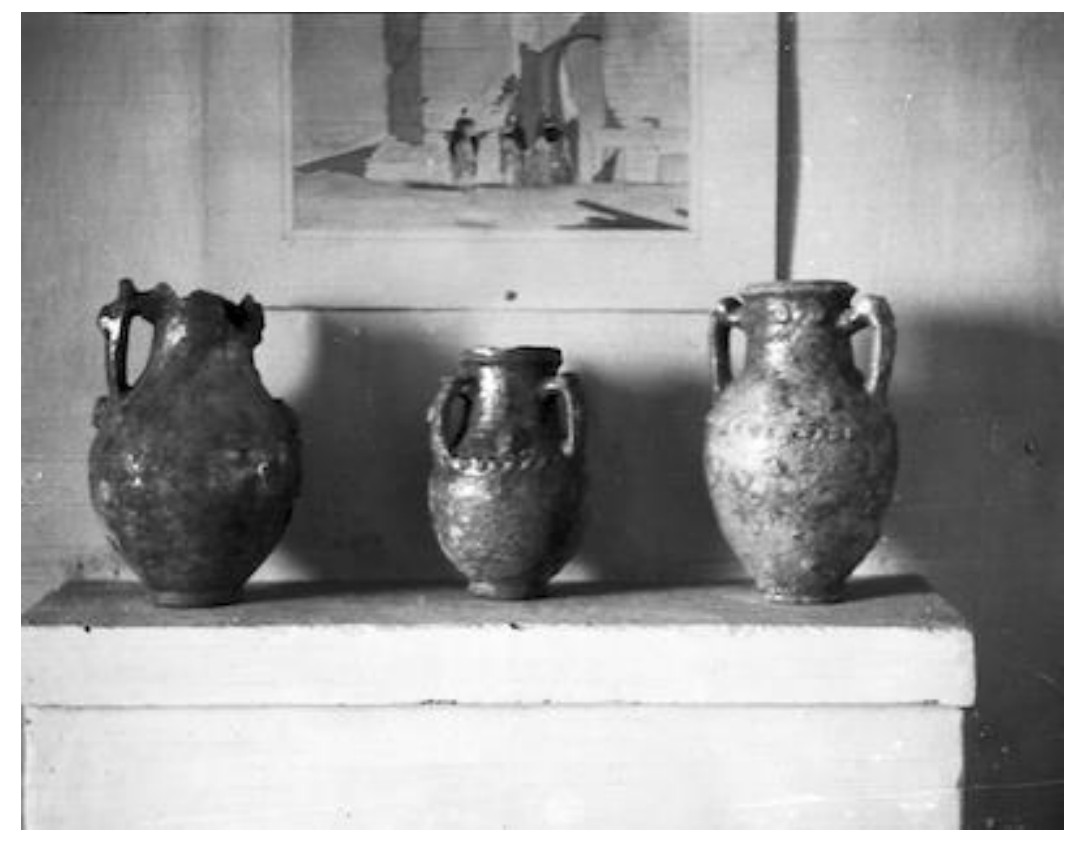

Figure 11: Three faience jars from a private house. Courtesy Yale University Art Gallery, Dura-Europos Collection Fiii63. Corresponds with Baird 2011, fig. 19. 


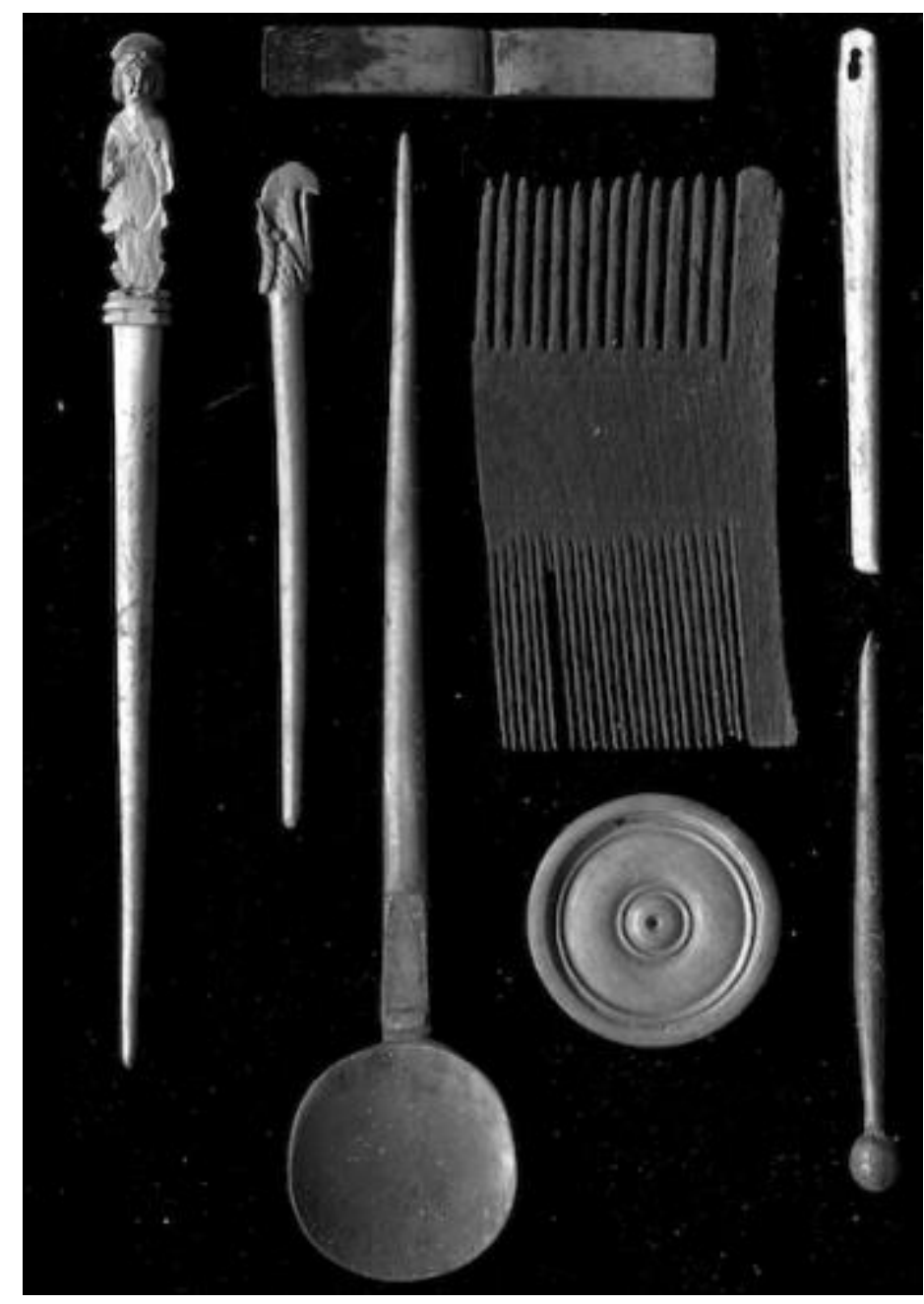

Figure 12: Bone objects from Dura-Europos. Courtesy Yale University Art Gallery, DuraEuropos Collection Dam-147. Corresponds with Baird 2011, fig. 22.

As we listened to the images of the artefacts (Figure 11 and Figure 12), the words we used to describe what we were hearing captured a kind of energy - 'frantic', 'desperate', 'nervousness', 'steady'. This is in contrast to the deliberate arrangement of the objects not as assemblages of finds but as objets d'art. When we first listened to Figure 11 (Baird's fig. 19) we described it as frantic and desperate, with a hollow plucking sound, reminiscent of a sonar ping, as if the music is searching. Perhaps the process is seeing the spaces between the vessels, or the hollowness of them. Is a vessel still a vessel if it's turned into a decoration? The clear framing of the three vessels, with the watercolour square in the centre, shows that the photograph is not documentation of an archaeological find (at least not in a scientific manner). It feels more like a trophy, to show the spoils, which perhaps we hear reflected in the hollowness of the song - or the act of adding duration to the image through sound causes us to see the hollowness of the archaeological practice. Figure 12 (Baird's fig. 22) depicts bone objects from private houses and the Dolicheneum at Dura, arranged against a black background. Again, we hear a hollowness in this sonification, which corresponds with the contrast between the objects and the background. We can hear and see where the artefacts are, laid out on a black cloth. The high contrast of what is clearly a collection/catalogue image lets us hear the artefacts, but it also makes us consider what's missing. The objects have been removed from their context and history, and are being treated as individuals without consideration of their wider story. The objects come from 'a variety of contexts', which 
are all lost in the image. The sonification drives home how the archaeologists decontextualised the objects, turning them into mere objects.

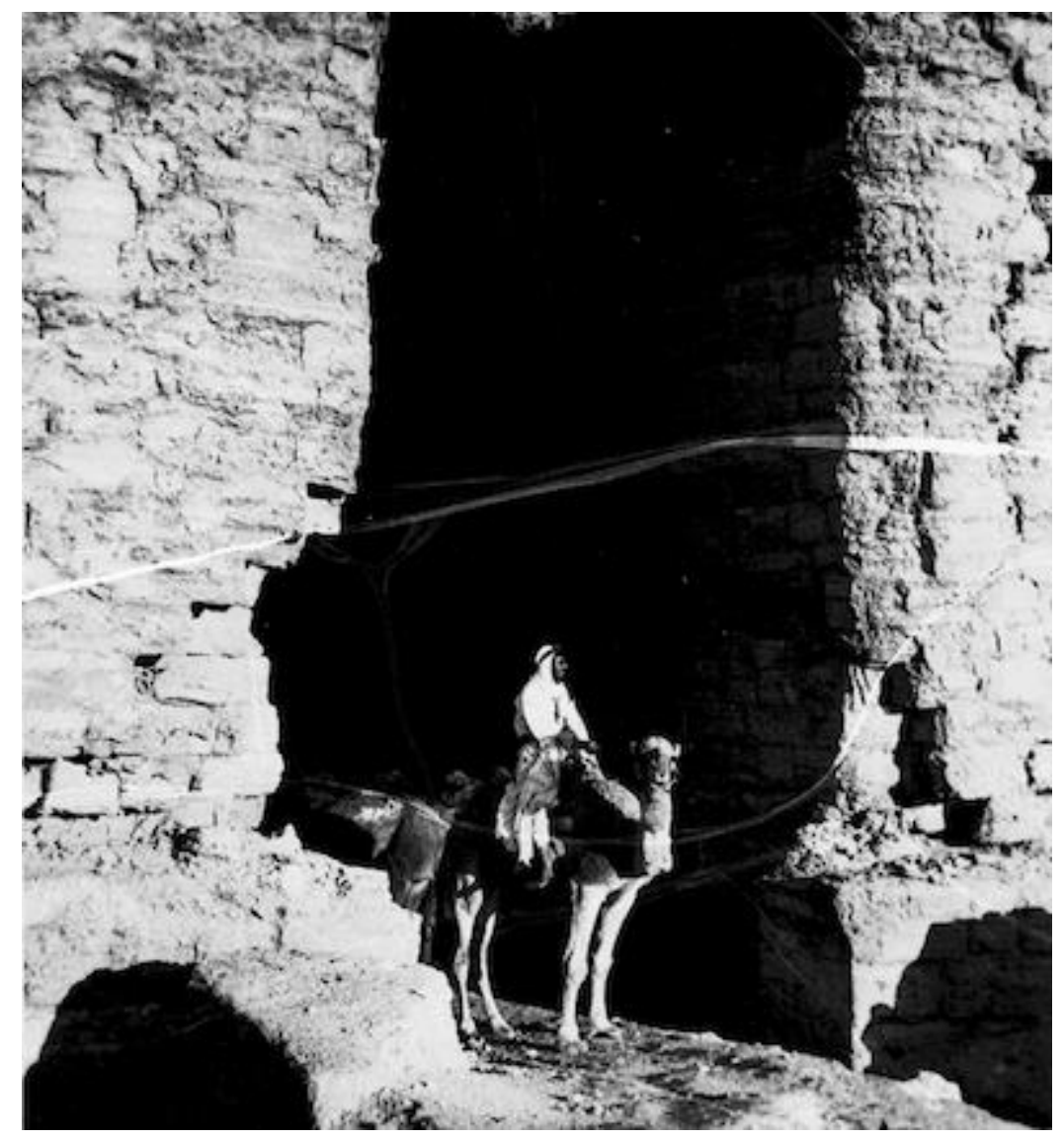

Figure 13: Man on camel in the Palmyrene Gate. Courtesy Yale University Art Gallery, Dura-Europos Collection, y-550. Corresponds with Baird 2011, fig. 18.

Baird points out how the images are used to fashion a motif of 'the exotic', and stereotypes of orientalising tropes that help to create a timelessness, an other (both contemporary, and in deep time); such a trope underlines the heroic endeavour of archaeology. Figure 13 (Baird's fig. 18), of a man on a camel in the Palmyrene Gate visually sets the tone; but as we listened to it, the music sounded hopeful. It is almost happy, and it makes us wonder if it captured the photographer's emotions. The image is listed in the archive with the additional information 'Christmas 1936'. While that may or may not have been of interest to any of the workers or locals, it clearly was important to whoever labelled this image (maybe the photographer). It also is the first image with an animal, and doesn't seem to have any archaeological importance. Instead, it feels and sounds like a sight-seeing or tourist photo. Here, the sound and the intent of the photograph work together to heighten the sense of alterity.

\section{Conclusion}

The point of sonification is to make us stop, pause, and reflect. It makes the archaeology strange again for us, which opens the door to enchantment. The juxtaposition of the songs from the photographs, with the content of the photos, changes our point of view in a synaesthetic experience; instead of looking at Dura Europos the way its excavators 
wanted us to, we see/hear instead the inequities of labour, race, class, and gender. Going further, if a large corpus of archaeological imagery were to be sonified, it might be that it is possible to detect sonic similarities that might correspond with particular ways of looking at the world. We might also suggest that sonification could have implications for how archaeological photography is conducted - how might the sound of the images push us to change how images are composed? Conversely, we can think about how the choices we made about systematising which pixel values to sonify are still subjective choices, and instead encourage the listener/viewer to reject our choices, and embrace the potential creativity the code allows. What other meanings might be lying latent, waiting to be made audible? Embracing this subjectivity reinforces that the choices we (that is, archaeologists in general) make in pursuing our archaeological methods always carry subjective, unacknowledged/invisible dimensions.

Returning to Rose Ferraby's 'poetry of algorithms', this method gives us a new lens to look through at the photographs, and allows us to complicate the intended narratives of the images, creating something new. Listening to the images-as-sound complicates the visual reality of the images, and allows us to look beyond the surface. It helps us think in different ways about the material presented. It adds depth, nuance, body and the images become more than 'mere' representations. It adds an emotional depth, reawakening a sense of the humanity of the individuals depicted. The images-as-sound renew attention to how photographs disrupt death, but leave the people and places still trapped in a forever moment. Images-as-sound make us pay attention to who is doing the seeing, and the unseen eye behind the camera viewfinder. Images-as-sound focuses our attention on how images are composed or scripted, and how that functions as a form of colonial violence by treating the images as truth. Finally, images-as-sound forces us to think beyond the frame, and listening to the gaps makes us confront the unseen/unshown. The people and labourers of Dura Europos cause the sometimes discordant, often sad, tone in these images-as-sound, in contrast to the narrative that the excavators wanted these images to create. Through the sonification, the workers regain a sense of life through their presence, and the absence of the archaeologists. Through the sonification, those who shovel are no longer silent.

\section{Acknowledgements}

We are indebted to Jennifer Baird, Michael Kramer, Colleen Morgan, and Katherine Davidson for invaluable encouragement and discussions around photography and sound; thank you to Megan Doyon of the Yale University Art Gallery for support working with the images. We are grateful for the generous and thoughtful reviews by the anonymous peer reviewers who pushed us further. This article draws on research supported by the Social Sciences and Humanities Research Council of Canada.

\section{Bibliography}

Baird, J. 2011 'Photographing Dura-Europos, 1928-1937: an archaeology of the archive', American Journal of Archaeology 115(3), 427-

46. https://doi.org/10.3764/aja.115.3.0427 
Bennet, J. 2001 The Enchantment of Modern Life: Attachments, Crossings, and Ethics, Princeton: Princeton University Press. https://doi.org/10.1515/9781400884537

Block, B. and Kissel, J. 2001 'Dance: the essence of embodiment', Theoretical Medicine and Bioethics 22(1), 5-15. https://doi.org/10.1023/A:1009928504969

Caraher, B. 2016 'Slow archaeology: technology, efficiency, and archaeological work' in E. Averett, D. Counts and J. Gordon (eds) Mobilizing the Past for a Digital Future: The Potential of Digital Archaeology, Grand Forks: The Digital Press at the University of North Dakota. 421-41.

Caraher, B. 2019 'Slow archaeology, punk archaeology, and the "Archaeology of Care"', European Journal of Archaeology 22(3), 372-

85. https://doi.org/10.1017/eaa.2019.15

Copplestone, T. and Dunne, D. 2017 'Digital media, creativity, narrative structure and heritage', Internet Archaeology 44. https://doi.org/10.11141/ia.44.2

Drimmer, S. 202114 April 'This is an excellent thread, to which I would add that the original photos themselves don't convey the vibrancy of reality in the past; rather they convey the vibrancy of *color photos* from the past.'

[Tweet] https://twitter.com/Sonja Drimmer/status/1382345548368334856 [Last accessed: 14 April 2021]

Edwards, E. 2001 'Photography and the performance of history', Kronos 27, 1529. http://www.jstor.org/stable/41056667 [Last accessed: 6 April 2021]

Ferraby, R. 2017 'Geophysics: creativity and the archaeological imagination', Internet Archaeology 44. https://doi.org/10.11141/ia.44.4

Ferraby R. and St John, R. 2020 Soundmarks http://soundmarks.co.uk/ [Last accessed: 13 April 2021]

Fredengren, C. 2016 'Unexpected encounters with deep time enchantment: bog bodies, crannogs and 'otherworldly' sites', World Archaeology 48(4), 482-

99. https://doi.org/10.1080/00438243.2016.1220327

Frieman C. and Gillings, M. 2007 'Seeing is perceiving?', World Archaeology 39(1), 416. https://doi.org/10.1080/00438240601133816

Geurts, K.L. 2005 'Consciousness as 'feeling in the body': a West African theory of embodiment, emotion and the making of the mind' in D. Howes (ed) Empire of the Senses: The Sensual Culture Reader, Oxford: Berg. 164-78.

Gibbs, F. and Owens, T. 2013 'The hermeneutics of data and historical writing' in J. Dougherty and K. Nawrotzki (eds) Writing History in the Digital Age, Ann Arbor: University of Michigan Press: Digitalculturebooks. 159-

70. https://doi.org/10.2307/j.ctv65sx57.18

Graham, S. 2016 'The sound of data (a gentle introduction to sonification for historians)', The Programming Historian. https://doi.org/10.46430/phen0057 
Graham, S., Reinhard, A. and Kansa, E. 2020

'Datacore', Epoiesen. http://dx.doi.org/10.22215/epoiesen/2020.6

Hamilakis, Y. 2017 'Sensorial assemblages: affect, memory and temporality in assemblage thinking', Cambridge Archaeological Journal 27(1), 169-

82. https://doi.org/10.1017/S0959774316000676

Hermann, T. 2008 'Taxonomy and definitions for sonification and auditory display' in P. Susini and O. Warusfel (eds Proceedings of the 14th International Conference on Auditory Display (ICAD 2008), IRCAM,

Paris. http://www.icad.org/Proceedings/2008/Hermann2008.pdf [Last accessed: 13 April 2021].

Hicks, D. 2020 The Brutish Museums: The Benin Bronzes, Colonial Violence and Cultural Restitution, London: Pluto Press.

Kramer, M. 2018 "A foreign sound to your ear': digital image sonification for historical interpretation' in M. Lingold, D. Mueller and W. Trettien (eds) Digital Sound Studies, Durham: Duke University Press. 178-215. https://doi.org/10.1215/9780822371991-009

Kramer, M. 2021 'What does a photograph sound like? Digital image sonification as synesthetic audiovisual digital humanities', Digital Humanities Quarterly 15(1). http://www.digitalhumanities.org/dhq/vol/15/1/000508/000508.html [Last accessed: 13 April 2021]

Kramer, M. and Noël, J-S. 2020 'Remediatizing visual media as sonic data. Sonification and cultural history', Revue d'histoire culturelle XVIIle-XXIe

siècles 2020(1). https://revues.mshparisnord.fr/rhc/index.php?id=348 [Last accessed: 13 April 2021]

Last, M. and Usyskin, A. 2015 'Listen to the sound of data' in A. Baughman, J. Gao, J-Y Pan and V.A. Petrushin (eds) Multimedia Data Mining and Analytics, Springer:

Heidelberg. 419-46. https://doi.org/10.1007/978-3-319-14998-1 19

Liu, A. 2020 'Data moves: libraries and data science workflows' in S. Mizruchi (ed) Libraries and Archives in the Digital Age, Cham: Palgrave Macmillan. 21119. https://doi.org/10.1007/978-3-030-33373-7 15

Manaris, B. and Brown, A. 2014 'Making music with computers: creative programming in Python', Chapman and Hall/CRC Textbooks in

Computing. https://iythonmusic.me/ https://doi.org/10.1201/b15104

Manaris, B. and Brown, A. 2016 'JythonMusic: an environment for teaching algorithmic music composition, dynamic coding and musical performativity', Journal of Music,

Technology and Education 9(1), 33-56. https://doi.org/10.1386/imte.9.1.33 1

Manovich, L. 2001 The Language of New Media, Cambridge: MIT Press.

McFadyen, L. and Hicks, D. 2020 Archaeology and Photography. Time, Objectivity and Archive, Routledge: London. https://doi.org/10.5040/9781350029712 
Mickel, A. 2021 Why Those Who Shovel Are Silent. A History of Local Archaeological Knowledge and Labor, Louisville: University Press of

Colorado. https://doi.org/10.5876/9781646421152

Morgan, C. 2016 'Analog to digital: transitions in theory and practice in archaeological photography at Çatalhöyük', Internet Archaeology 42. https://doi.org/10.11141/ia.42.7

Perry, S. 2018 'Why are heritage interpreters voiceless at the trowel's edge? A plea for rewriting the archaeological workflow', Advances in Archaeological Practice 6(3), 212227. https://doi.org/10.1017/aap.2018.21

Perry, S. 2019 'The enchantment of the archaeological record', European Journal of Archaeology 22(3), 354-71. https://doi.org/10.1017/eaa.2019.24

Pink, S. 2009 Doing Sensory Ethnography, London:

Sage. https://doi.org/10.4135/9781446249383

Riggs, C. 2020 'Archaeology and photography' in G. Pasternak (ed) The Handbook of Photography Studies, New York: Routledge. 187-

205. https://doi.org/10.4324/9781003103974-15

Samuels, L. and McGann, J. 1999 'Deformance and interpretation', New Literary History 30(1), 25-56. https://doi.org/10.1353/nln.1999.0010

Shanks, M. 1997 'Photography and archaeology' in B.L. Molyneux (ed) The Cultural Life of Images: Visual Representation in Archaeology, London and New York: Routledge. 73107.

Sterne, J. and Akiyama, M. 2012 'The recording that never wanted to be heard and other stories of sonification' in T. Pinch and K. Bijsterveld (eds) The Oxford Handbook of Sound Studies, Oxford: Oxford University Press. 544-

60. https://doi.org/10.1093/oxfordhb/9780195388947.013.0115

Supernant, K., Baxter, J. E., Lyons, N., and Atalay, S. (eds) 2020 Archaeologies of the Heart, Cham: Springer. https://doi.org/10.1007/978-3-030-36350-5

Tringham, R. and Danis, A. 2020 'Doing sensory archaeology: the challenges' in R. Skeates and J. Day (eds) The Routledge Handbook of Sensory Archaeology, London: Routledge. 48-75. https://doi.org/10.4324/9781315560175-4 